\title{
Nationalism and national unity in multi-ethnic Nepal: Adopting integrative approach for managing national affairs
}

\section{Bihari Krishna Shrestha}

\section{Abstract}

The birth of the concept of nationalism and national unity happened in Nepal, more or less at the same time as in Europe, by the second half of the Eighteenth century. Nationalism is seen as an ideology that demands loyalty and devotion to the notion of authority from individuals or groups. While Nepal has come a long way in the process of growth of nationalism and national unity, they have been nurtured by significant nation building measures at important junctures in Nepal's history. But recent events have shown that they remain vulnerable to external adversaries and influences and interventions. Indeed, the founding father of the modern Nepal, King Prithvi Narayan Shah's dictum, "Nepal as a yam between two boulders" remains equally valid ever for Nepal's foreign policy. A metaphor of "yam" in his maxim connotes Nepal's geo-strategic position which, like a soft edible starchy staple food in tropical and subtropical areas, has to maintain its balanced relations with two big powerful countries like boulders. Thus, this paper argues that located in such an intricate geographic position, Nepal has to protect its existence as a nation-state internally through integrative, participatory and inclusive national development approach, and externally, by balancing relations with the two big neighbors to forestall their undue pressures.
Keywords: nationalism, national unity, external threat, ethnicity, integrative approach

\section{Introduction}

Nepali nationalism and Nepali nationstate evolved almost along the advent of nationhood in Europe and America. The birth of the Nepali state and Nepali nationalism were nearly simultaneous and predated by a few years in the eighteenth century American Revolution of 1779 and the French Revolution of 1789 which are taken as "first powerful manifestations" of nationalism in the world (Kohn, 2019), King Prithvi Narayan Shah had laid the foundation of the state of Nepal in 1768 AD with his victory of the three states in the Kathmandu Valley and defined it as the "garden of four Varnas and 36 Jats" in his Dibya Upadesh (The Great Guidance), meaning, the new country belonged to all its people. However, given Nepal's limitations in academic advancement until in recent years, the subject of Nepalese nationalism as of many other subjects in such a multi-ethnic country have been examined mostly by foreign scholars and researchers, prompting Prayag Raj Sharma to observe that "Nepalese have learnt about Nepal more through the writing of these foreign researchers than through works written by the Nepalese themselves" (Sharma, 1997, p. 473). However, there is a danger to it, as observed by another Nepali scholar, Harka Gurung, in that " the ethnic minorities tend to view the printed exposition 
of foreign researchers as more authentic" even as such studies could suffer from what he called a "nexus between the outside and marginal perspectives" although there could be "divergence in perception"depending on "whether they (the researchers) subscribe to dominant or marginal aspect viewpoints (sic)" (Gurung, 1997, p. 497). This weakness seems to manifest itself also in the discussion of nationalism in Nepal when Oxford professor, David Gellner criticized Prithvi Narayan Shah for his "indifference to the question of language" to which Sharma rebutted by observing that "this sounds somewhat like blaming Queen Elizabeth I for not allowing women to vote in her time in England" (Sharma, 1997, p. 480). Similarly, Frederick $\mathrm{H}$. Gaige, a young man, restless and looking for adventure by his own admission, had made into Nepal in 1966---that is, six years after King Mahendra's takeover of the reins of government in 1960---and based on what clearly was a rushed study of "selected villages" in the five Terai districts stretching from Jhapa to Kailali assisted by a "Mithila Kshyatriya interpreter" within a few months between the "end of monsoon" and "before the hot weather set in" in 1967-68 examined King Mahendra's "leadership in formulating and implementing domestic policies" as "neither forceful nor progressive" (Gaige, 1975 , p. 204). He was evidently oblivious of the larger picture of the nation at the time when many historic reforms propelled by the monarch.

Whereas much of Nepal's history until the breakdown of the Anglo-Nepal War in 1814 was characterized by conquests and expansions of the country, a century (18461951) under the Rana regime in Nepal was marked by isolationism and authoritarianism. Subsequently, the thirty years of the Panchayat system (1960-1990) was marked by attempts at cultural homogenization and restrictions to freedom of expression. However, following the restoration of liberal democracy and multi-party system, Prithvi Narayan Shah's dictum of "Nepal a yam between two boulders" has received an ever -increasing gravity and significance in Nepal's foreign policy. In such an escalating relevance of PN Shah's maxim, Nepal has been responding new initiatives from both India and China, boulders in the Founder King's metaphor. In such an intricate geo-strategic position, Nepal should be able to maintain fair and balanced relations with these two immediate neighbors in line with the Founder King's principle to protect its existence and sovereignty. These recent dynamics, thus, add new dimensions to the discourse of nationalism particularly when it comes to an ethnically diverse, poor and landlocked country like Nepal. This paper, therefore, briefly examines the nature and challenges of the new dynamics.

\section{Conceptual overview}

It is observed that "throughout the history people have been attached to their native soil, to the traditions of their parents, and to established territorial authorities, it was not until the end of the eighteenth century that nationalism began to be a generally recognized sentiment molding public and private life and one of the great, if not the greatest, single determining factors of modern history" (Kohn, 2019). The American and French revolutions are taken for the "first powerful manifestations", and by the beginning of the 20th century, nationalism flowered in Asia and Africa too. (Kohn, 2019)

Published in 1983, a couple of prominent works, including Serious literature on the 
subject of nationalism: Ernest Gellner's Nations and Nationalism and Benedict Anderson's Imagined Communities: Reflections on the Origin and Spread of Nationalism explore issues of nationalism and nationhood.

Gellner, a British Czech philosopher, describes as "prolific and witty philosopher, anthropologist, sociologist and multilingual polymath", nations and nationalism are "products of modernity and have been created as means to political and economic ends" (Gellner, 1983). According to him, "It is nationalism which engenders nations." Gellner postulates that "nationalism is primarily a political principle that holds that the political and the national unit should be congruent". That is, the people in a state must share a common sense of nationalism and vice versa. From this perspective, "Nationalism appeared and became a sociological necessity only in the modern world (where) work becomes technical" necessitating" impersonal, context-free communication and a high degree of cultural standardization". Gellner's theory about nationalism has often been critiqued. One such criticism pertinent to this paper has it that "The suggestion that nationalism cannot tolerate ethnic, racial or religious differences is refuted by the existence of multi-ethnic, multi-racial and multi-religious nations" (Kakeyi, 2012).

Anderson defines nation as an imagined political community. People of a community have their fellow members outside somewhere their geographic locations. At the same time, those people who do not live in physical proximity share much of their lifestyles and worldviews with citizens of different nations and communities. In Imagined Communities, Anderson explicates:
In fact, all communities larger than primordialvillagesofface-to-facecontact (and perhaps even there) are imagined communities are to be distinguished, not by their falsity/genuineness, but by the style in which are imagined. Javanese villages have always known that they are connected to the people they have never seen, but these ties were once imagined particularistically-as indefinitely stretchable nets of kinship and clientship. (2016, p. 6)

Anderson opposes the idea of nationalism as an awakening of people of a particular territory or nation in a literal sense of the term. Nor does he agree with the concept of nationalism as a strong feeling of nationhood of people living in a particular nation-state in a conventional fashion.

After the Second World War (1939-45), nations and citizens across the world started responding large corporate institutions, such as World Bank and International Monetary Fund for their saviors and missions to connect themselves to the world communities. Moreover, Europeans counties are connected with European Union, whereas the world citizens are connected through a process of modernity and globalization.

\section{Nationalism in Nepal: Some historical antecedents}

In view of the international experience briefly discussed above, the growth of nationalism in Nepal constitutes a category by itself even as it also shares parallels with the experiences of the West. Firstly, in contrast to the countries in Europe in particular where, as per Gellner, nationalism evolved as a necessary condition of modernity, in Nepal, the birth of the state of Nepal and its nationalism had been more or less temporally co-terminus, and amidst 
highly traditional context. As mentioned earlier, the Nepali nation was put together by King Prithvi Narayan Shah in 1768 AD through his conquest of numerous principalities, and just a few years thereafter he had gone on toenunciate the making of the Nepali nationhood in his Dibya Upadesh (The Great Guidance) in which he envisioned the nation state as "the garden of four Varna and thirty six Jat". This definition not only demanded unquestioned loyalty of all its countrymen; it was also to be the place for prosperity for all of them, irrespective of their caste status. While King PN Shah has since been immortalized as the Founding Father of the Nation, he had also fired the imagination of his successors who continued to carry on his campaign of conquest and expansion for nearly another half a century until Nepal'sdefeat in the Anglo-Nepal War of 1814-16. Even thereafter, its military ambition towards the north into Tibet sustained and eventually resulted in the acquisition of exclusive trading rights in Tibet among others.

Although Nepal's unification as a nation and its rise as military power in the lap of the Himalayas were attained in a span of less than half a century, it had also been transformed into a nation state that formally demanded Kohn's quote of "loyalty and devotion" to the state, implicit in PN Shah's Divya UpadeshIt is interesting to note that long before Gellner' and Anderson's seminal work on nationalism were written (in 1983) the sixth chapter of one of the earliest Nepaliauthored history books on Nepal, Nepalko Aitihaasik Rooprekha (The historical shape and contours of Nepal), first published in 1951,was titled Rastriyatako Bikas or Growth of Nationalism, and dealt with the rise of Shah dynasty and the establishment of Nepal as a nation state, and its sustained expansion by PN Shah's successors, Queen Rajendra Luxmi Devi from 1777 to 1786 and her brother-in-law Bahadur Shah (1786 to 1795 ), both working as regents to the then infant king, Rana Bahadur Shah (Sharma, 1951, pp. 198-321).

In some ways, Nepal's nationalism has some parallels to that of the West in terms of its external threats and people's realization of the power of unity to face any kind of intimidation. For instance, Prithvi Narayan Shah's characterization of Nepal as the "yam between two boulders" in his Divya Upadesh, just signifies this threat potentially posed by China on one side and the then British India on the other. The dictum was prophetic. Not too long thereafter, Nepal did fight vicious wars with China in 1792 and with British India in 1814 that only consolidated the perception of continuing threat from either side. Ever since India became independent in 1947 , the threat perception turns into a reality in forms of several blockades and recurring interventions in the internal-domestic affairs. In fact, it was to insulate this "yam" i.e. Nepal from possible mortal pressure from India that King Mahendra took over the reins of government from elected BP Koirala government in 1960--to the widespread criticism of the move internationally--and as his very first act as country's head of government, went on to China to get that country's help to get a road built to the northern neighbor too, by opening up what was seen in India as Fortress Himalayas in the north. While that did not deter India from creating problems for Nepal particularly in trade and transit to the world beyond, the road precluded the loss of Nepal's sovereignty as happened to Nepal's next door neighbor, Sikkim, that was annexed to India in 1975, 
Much of how India continued to interfere in Nepal's internal affairs till the recent times has been well described in the seminal work, magnum opus, by Nepal's eminent journalist, Sudheer Sharma, in his recent publication fittingly called "The Nepal Nexus (Sharma, 2019). Lately, Nepal has managed to work with China to open up alternative access to third countries for international trade through Chinese ports, thus, ending Nepal's exclusive dependence on India for the purpose. All these developments only show that on-going external threat perception remains a potent force in the making and managing of the Nepal's nationhood

\section{External players in recent dynamics in nationalism and national unity}

\section{Nepal's ethnic diversity}

While Nepal remains a highly diverse country ethnically, it is this attribute that has been at the centre of recent dynamics regarding Nepal's sense of shared nationalism and national unity. Nepal's cultural landscape is comprised of some 100 plus ethnic and caste groups living mostly in mixed multiethnic settlements. According to the 2011 census, the total population numbered 26,494,505 which is comprised of 125 castes/ethnic groups of which only two (caste) groups have double digit population namely, Chhetri (16.6\%) and Hill Brahman (12.2\%). Of the ethnic (tribal) groups, the most populous are traditionally-hill-dweling Magars (7.1\%) followed by Tarai-dwelling Tharu (6.6\%), hill dwelling Tamang (5.8\%), Kanthmandu valley dwelling Newar (5\%) and so on. While, according to the government sources, there are 59 different ethnic groups, now officially designated as Janajati groups in the country, another study in 2010 reported the existence of more than 80 janajati groups
(Onta, 2011). Besides, as mentioned above, almost all of these caste/ethnic groups live in ethnically mixed settlements, creating over the centuries multiple institutions of cooperation and coexistence, including a shared pantheon that comprised of more than the known Hindu or Buddhist deities. Almost all village communities, while characterized by mutual inequities and cultural differences, lived in harmony that was essential for eking out existence in their harsh environments. For instance, the western terai district of Kailali has 43.3 percent ethnic Tharus who live alongside Hindu caste groups of Chhetri (17.42\%), Brahmin (10.73\%) and Thakuri (2.93\%), Tibeto-Burman Magar (3.88\%), and the dalit castes of Kami (6.81\%) and Damai (2.10\%) plus "others" (12.41\%) (Kailali DDC, 2009). Similarly, the central hill district of Dhading has 69 different caste ethnic groups in its total population of 173,000 (2001), of whom the numerically dominant ones are the Tibeto Burman -Tamang $(73,000)$, Newar $(32,000)$, Magar (29,000), Gurung (26,000), Chepang $(11,000)$, and Kumal $(4,000)$ and the IndoAryan caste groups of Brahmin $(57,000)$, Chhetri $(53,000)$, and the dalit caste groups of Kami $(11,000)$, Sarki $(14,000)$, and Damai $(8,000)$ (Dhading DDC, 2002).

Of the total population of $13,318,705$ (2011) in the 20 districts comprising the Terai belt, people of hill origin, generically referred to as pahari or pahadi represented $39.86 \%$, Madhesi caste groups $38.71 \%$, Tharus and other Taraitribals 12.64 and Muslims $8.32 \%$. While the pahari population of the Terai represented the kaleidoscope of 59 caste and ethnic categories from the hills, the Madhesi population comprised of $49 \mathrm{high}$, middle and low caste groups, the latter two categories constituting the vast majority of the Madhesi population. Thus, both the hill and Terai 
regions of Nepal represented a very vast ethnic diversity, most settlements consisting of a large plurality of the caste and ethnic groups.

\section{Primacy of external players in fomenting divisive dynamics}

But the yam between two boulders remains a volatile entity. While there has been some organizations along ethnic lines during the early 50s and the restrictive Panchayat period (1960-90), they were either just welfareoriented ethnic organization like Gurung Kalyan Sangh and Tharu Kalyankari Sabha of 1956 or the post-referendum (1937) Magurali informal coalition (Gurung, 1997, p. 526), conceived for some political leverage. It was only after the restoration of the libertarian democracy and multi-party system in 1990 that an ethnicity-based movement got under way in real earnest. The umbrella organization of ethnic groups in Nepal, the Nepal Federation of Indigenous Nationalities (NEFIN), composed of 59 distinct ethnic groups, recognized by the government, was first established in 1991 as Nepal Federation of Nationalities, (NEFEN) representing 21 groups at the time, generically referred to as Janajati or "people castes". However, after the United Nations General Assembly announced The International Decade of the World's Indigenous People (19952004) in December 1993, the then NEFEN too organized a conference in 1994 and renamed themselves The Nepal Federation of Indigenous Nationalities (NEFIN). Probably to be eligible for UN largesse, they defined the term, "indigenousness" as being "in opposition to Hindus". Other labored criteria included: possessing their own original lingual and cultural tradition, faith based on ancient animism, not Hinduism, ancestors being the first settlers in the state but now displaced from their own land for the last 4 (sic) centuries and "whose society was traditionally erected on the principle of egalitarianism - rather than the hierarchy of the Indo-Aryan caste system" and so on. But since the leadership of the new movement included social scientists too, they knew that these criteria were contrived more to qualify for the UN's "indigenous people" badge and its funding, as well as to gain some political clout in the libertarian atmosphere where political parties vied for support by fair means or foul.

Then there were bilateral donor agencies whose largely Western officials came mostly with colonialism-generated experience of segregation and conflict based on color and religious differences in their own societies. They sorely lacked any serious acquaintance with the distinctive sociology of Nepalese life and therefore, found it easy to identify with the contrived "indigenousness" and claim of discrimination of the Janajati ensemble and opened up their purse strings liberallyto NEFIN to apply their newfound leverage as political players of note too. They mainly hounded the Bahuns (Brahmin) who were branded as immigrants from India and, given thelatter'srelative prosperity as a caste group, were also termed as the main exploiters responsible for keeping the Janajatis impoverished and powerless. There were academic voices that said that the ground reality completely differed from NEFIN claim but that did not make any difference to their stance (e.g. Dahal, DR, 1995; Sharma, PR, 1997: 489; Shrestha, BK, 2012) for a long time. A British scholar even had gone to the extent of expressing his frustration thus: 
"there is a bitter irony in the fact that just when a scholarly and anthropological consensus is emerging that a Hindu-tribe dichotomy was hopelessly flawed as a tool for understanding Nepalese society, Nepalese intellectuals themselves should begin to take it up with a vengeance" (Gellner, 1997, p. 22).

Then came the Maoists, mostly based in India (Sharma, 2019). While their earlier avatar as a political party had only nine members in the newly elected parliament in 1991, they took violence for a fast track to resort to power. They too found it convenient to support and use the NEFIN demand for federalization of Nepal based on ethnicity and find favor with the Janajati organizations across the country. In the First Constituent Assembly of 2008, there were many members who sounded and behaved as die hard NEFIN representatives and tried to force the creation of ethnicity-based federal provinces in the new constitution, such suggested provinces variously numbering 14, 12 or 11 at different times at the whim of mainly the Maoist and "Janajati" members. However, by the time the second constituent assembly (2013) was ready to pronounce a new constitution, the donor funding sources--that had come under severe criticism in the country--had dried up and consequently, these "ethnic rebels" too had gone out of steam with the major diehards quietly relinquishing NEFIN leadership. While the new Constitution of Nepal 2072 (2015) federated the entire country into seven provinces, they are not based on ethnicity, except Province 2 in the Terai which is the product of another "ethnic strife" based on the purported differences of the "Madhesi" people.

\section{The Madhes turmoil}

Until the fifties of the last century, the Terai plains remained isolated from the rest of Nepal because of the malarial forest belt. Inhabited by indigenous ethnic groups, such as Tharus and Majhis, the Madhes is isolated between lower hills to the North and the Terai to the South was also populated with indigenous people from India during the time of the Gorkha conquests This Madhesi community comprises mainly the Maithili speaking community in the eastern Tarai, Bhojpuri in the mid-Terai and Awadhi in the western and is the spillovers into Nepal of the vast population of similar linguistic background across India. As observed by Claire Burkert regarding the Maithili culture, who worked among these people:

The culture of Maithil people extends from Nepal's eastern Tarai into Bihar in India, and the region has unofficially retained the name of Mithila. During the age of the Videhan kings, Mithila was a kingdom and Janakpur (now in Nepal) its capital. (Burkert, 1997, p. 241)

This intercourse between the hills and the Terai people, despite the control of malaria and development of road and other communication network remains woefully limited, creating its own problems of perception in the process. This problem is most eloquently explained recently by a Terai intellectual and activist, Rajesh Ahiraj, who, speaking to online new portal, Desh Sanchar in February 2018 (Falgun 29, 3075) said that 90 percent of the Madhesis die without reaching the Himalayas and more than that proportion of the hill people die without ever visiting the Janaki Temple in Janakpur. As a result, the Madhesi do not know sufferings of women in Humla and Jumla where they have 
to spend some three hours just for fetching a pitcher of water every day and that people sometime die for want of even one single table of citamol. He maintained that except for a handful of people on either side, there is absolutely no acquaintance between the people of the hills and the Madhes. Therefore, along with the geographical unification, there is also a compelling need for promoting emotional bond between the two people. Eventually, only the interests of the individual leaders of Madhes have been taken care of, and the overall agenda of Madhes integration remains undone. The people of the hills have to know that the dhoti wearing people too are Nepali as well (Ahiraj, 2018)

While much remains to be accomplished in the Madhesi-hill integration in Nepal, it has turned out a seriously sensitive political problem, often punctuated by calls for the Terai secession. Like the Janajati turmoil in the hills, the Terai remains a paradox. In the sixties on the last century, the aforementioned American researcher, Frederick H. Gaige, based on socio-economic study of the region, had written:

The process of acculturation did not extend to the people of the Tarai, partly because of the country's geography. The Tarai people were isolated from the hill people by the dense and malarial forest that separated the two regions of the country. (Gaige, 1975, p. 96)

He had gone on to add that "Despite resentment with Nepal government's economic policies in the rural areas of the Terai and resentment against the government's efforts at Penalization in the urban centers, the Terai is not a sea of discontent, ready to drown the government in the high tide of revolution" (Gaige, 1975, p. 193). However, while writing an Introduction to the reprint of Gaige's work in 2009, Arjun Guneratne (2009: xvi) observed, "Thirty years later, the situation is different, and the new republic faces the most difficult challenges in the Terai".

The challenge has been summed up by Sudheer Sharma recently in his aforementioned work, The Nepal Nexus where he observed that "For years, the region had been seething with concealed anger over the tendency of Kathmandu to lump together the natives and Indian immigrants and treat them with disrespect and discrimination." While they also resented "the growing migration of the people from the hills" the Madhesi community "had been unhappy over difficulties in getting Nepali citizenship, prohibition on the official use of local languages, minimal representation in organs of the state and so on (Sharma, 2019, pp. 276-77)

Despite the passions raised in regard to the Madhesi cause, the problem is much more enigmatic in content. For one thing, compared to the days of Fred Gaige, the Madhesi people, who speak Nepali, are much more engaged in the rest of the country. While there has been more arrival of Indian immigrants, so has the influx from the hill region too. According to 2011 census, the Terai represents 50.3 percent of country's population, a significant increase from 36.4 percent in 1961 and 48.4 percent in 1991 . However, of the total population in 20 Terai districts (2011), the people of hill represent $39.86 \%$, whereas the corresponding proportion for the Madhesis is $38.71 \%$ ( $19.5 \%$ in the country's population) and the rest comprise of Tharus represent $12.64 \%$, Muslim $8.32 \%$ and others $0.48 \%$. Besides, as reported Chandra Kishore, a widely respected journalist from the Terai, in 2012, the roti-beti based "south-oriented outlook' was undergoing change. The new 
generation of Madhesis is now "more inclined to embrace Kathmandu than the traditional destinations like Darbhanga, Madhuvani, Sitamadhi, and so on". Besides, "there was dissatisfaction over the hegemony of the new arrivals from across the border who managed to acquire Nepali citizenship". For him, the Madhes revolt (of 2007) itself was "a process of "abharatiyakaran" (deIndianization). He concluded, "while living in Kathmandu continues to involve some challenges", for the most part, "it has now become sajhasahayatra" or a shared voyage (Kishore, 2012).

Then, there is an issue of severe stratification among the Madhesis themselves. For instance, in the population given above, the three high caste groups of MadhesiBahun, Kayastha and Rajputs together represent only $4.2 \%$ in the total Madhesi population. But they remain dominant economically, socially and politically and appropriate much of the government benefit meant for the Madhesi people for themselves. In this regard, a Madhesi professor complained that the high caste Madhesis have all along been getting appointments as Badahakim, judges and officers from the days of the Rana and Panchayat regime, had become ministers, chief justice, ambassadors and zonal commissioners in 2012. In democratic and republican structures, Machesis have become ministers, legislators, ambassadors, and CEOs in various corporations. It is these high caste people such as Maithili Bahun, Bhumihar, Rajput and Kayastha who appropriate the opportunities from the government reservations made for the Madheshi people in general. These same high caste people have most of the land in the Terai whereas the lower caste people are virtually landless the author warns that if this problem is not addressed in time, there may eventually be a new conflict between high caste people and Dalits of the Terai (Dev, 2012).

If Frederick Gaige had not seen any possibility of a revolution then, it should have been even less likely in what is now more of a propitious situation in the Terai. But as Gunaratne (2009) put it, "Thirty years later.... the new republic faces the most difficult challenges in the Tarai". He added, "Why that should be the case is a story waiting to be told".

There are considerable answers to be found in the recent work by the aforementioned journalist, Sudheer Sharma (2019). While he too subscribed to the long-running "anger over the tendency of Kathmandu to lump together the natives and Indian migrants and treat them with disrespect and discrimination" (Sharma, 2019, p. 276), we were told by Gaigesome three decades ago that it is not a sufficient condition for a revolution. While India has been known to stir up problems in the tarai all along, according to Sharma India's interest in the Madhes "grew exponentially following the appointment of Shyam Saran as Delhi's ambassador in October 2002" who brought all the India-assisted major projects to the Terai, managed to spend up to NRs. 50 million of development assistance directly in the Madhes, and opening of the Indian Consulate Office "in the heart of Madhes, at Birgunj" that coincidentally "witnessed unanticipated turmoil" in the Madhesh (Sharma, 2019, pp. 280-81). Sharma went on to add that "Less than two months after the Gaur massacre, on 27 May (2007), there was an attempt to assemble all the armed and unarmed forces of Madhes together at a meeting in Patna, Bihar. Madhesi leaders of all hues, from MJF (Madhesi Janadhikar Forum) Chairman Upendra Yadav to Jwala Singh, the leader of an armed outfit that raised separatist slogans 
and engaged in violence were present. The unseen organizer of the meeting was the newly opened Patna RAW station. The aim was to form a common front of all Terai forces, selecting a consensus leader of the front, and start a campaign for an "independent Madhes" by seeking international support" (Sharma, 2019, p. 289). Ram Raja Prasad Singh, then a prominent republican leader from Saptari, was projected as the leader of the campaign. ... But when he himself remarked at the meeting that he 'could not even imagine becoming the president of the Tarai by disintegrating the nation', the Patna mission collapsed" (Sharma, 2019, p. 290). Sharma further added that In India the Congress party, the Bharatiya Janata Party, the Indian army, and domestic intelligence agency IB were in favor of preserving Nepalese monarchy in some form but the South Block, and RAW were in favor of a republic. The then Indian Ambassador Shiv Shankar Mukherjee himself--who had often felt disrespected during the royal regime--also favoured a republic. When Pranab Mukerjee, a fellow Bengali, stood in favour of a republic,'the embassy was given instructions to carry out policies and programmes accordingly" (Sharma, 2019, p. 209).

However, there has been some very significant changes in India's approach to Nepal after Nepal turned to China, particularly following India's extended blockade of Nepal in 2015. Today, China's presence in Nepal is significant and, going by the writings in the Indian news media India does view it with concern. Now that India's muscular diplomacy with Nepal has become counterproductive for that country, lately, it has become much more conciliatory towards Nepal, tending more towards a win-win relationship

\section{Conclusion}

The preceding discussion lead to the compelling conclusion that while the sense of shared nationalism among the people remain largely robust andthateven the long alienated Madhesi people have come around to share in and claim this common nationhood, the recent events--the turmoil set forth by the Janajati activists, the Maoists' rise and rampage with India's support and the Madhesi revolution of the last decade-show that nationalism as a binding force in Nepal remains fragile and vulnerable to external intervention, however unwitting as in the case of the janajati activists' claim to indigenousness of Nepal's ethnic groups. Nepal's nationalism needs to be nurtured with utmost care. In a sense, Nepal's experience with its nationalism project is comparable with that of Spain where, having made the problem of Basque separatists go away, the state is now struggling with the Catalonian separatists. A recent report in the Foreign Affairs magazine said,

Compared with neighboring states such as France, the Spanish nation-building project was unusually weak, in part because the state spent its resources less on the building blocks of a common national identity, such as mass schooling, and more on maintaining a financially ruinous empire abroad. That historical weakness shapes Spanish national consciousness to this day. It is evident in the country's deep distrust of subnational diversity and the widely held belief that distinct national identities threaten rather than complement the Spanish state. (Ballcells, 2019)

In the case of Nepal, for many years, there has been no strident call for strengthened nationhood other than Prithvi Narayan's exhortation of the "Garden of all four Varnas and 36 castes" and his call for handling the 
"yam between two boulders" with utmost care. However, there has been significant moves for strengthening nationalism during King Mahendra's time in particular like making Nepali currency the only legal tender all over the country, introducing Nepali as the medium of instruction and the abolition of the discrimination based on the caste system. However, the Janajati turmoil and the Madhesi uprisings show that Nepalese's sense of shared nationalism can easily be destabilized through the spread of false information designed to capitalize on the inherent inability of the masses to discern the sinister design largely due to lack of education. This has been the situation capitalized by the handful of Janajati activists, the Maoist insurgentsorthe Madhesirebels in their mission of destabilization.

There is a need for integrative approach to national development and to foreign affairs for protecting and nurturing nationalism and national unity.

This is where Prithvi Narayan Shah's dictum of Nepal being the "yam between the two boulders" and "garden of four varnas and 36 castes" come in as a challenge to be continuously managed and nurtured. That can be done through the adoption of integrative approaches to national development on the one hand and managing Nepal's foreign relations in a manner that would discourage fomenting conflict and discord among the Nepalese themselves by foreign players in and outside Nepal.

In regard to foreign relations, Nepal must constantly bear in mind the "yam and boulders" analogy in that we have to manage the two boulders in such a way that the health of the yam in between is not compromised with either of the two boulders leveraging undue pressure on it. Nepal's own recent experience should illuminate the proposition. While the 2015 blockade of Nepal, for instance, represented undue pressure being exerted by the "boulder" to the south, the country's recent determined move to get closer to the northern "boulder", China, produced its own energy that seem to have deter the southern boulder from putting undue pressure on the squashy and delicate "yam" in between, i.e. Nepal, thus, assuring the Nepalese that India will no longer be able to blockade Nepal again for one thing. Similar policies will have to be adopted with the wide variety of external agencies working in Nepal, many of whom, through their power of purse and acquiescent counterparts in and out of the government have learnt to take Nepal for granted and push their own sinister agenda with complete impunity. The external support for the contrived Janajati case and Nepal's acquiescence to allow the then Indian ambassador to disburse direct grants of upto 50 million rupees resulting in Madhes conflagration discussed above come in handy as relevant lessons of experience in this regard.

Nationally, our approach to national development must be integrative in character. For one thing, Nepal has already made a very significant move to this end by changing its national anthem to one that is highly integrative in its letter and spirit. Unlike the former one that extolled the magnificence of the king in throne, the new one specifically makes reference to three geographical regions of Nepal, the Terai, hills and mountains as well as to being a pluralist nation. But much more needs to be done in this direction such as making the list of national icons inclusive too. 
However, it is the development process that has to be made inclusive and participatory, so that all the citizens of the country can own up and benefit from it, thus engendering a strong sense of belonging and ownership. This can happen only if the governance authority is devolved to the grassroots, so that it comes within reach of every single members living in those ethically mixed communities. Incidentally, such an approach is also very effective in delivering the intended benefits and accelerating the pace of progress. Nepal already possesses such feathers of success on its cap. These initiatives have not only effective domestically but also remain applauded around the world. Nepal's community forestry project is one such success story under which all the users of a given forest are legally empowered members of their Forest User Groups (FUG). To briefly dwell on its astounding success, Nepal's forest wealth was nearly totally denuded to the point of near desertification by mid1980s due to its nationalization in 1957. In 1988, Nepal introduced the FUGs and empowered them by special legislation to manage their own forest. The result was a miracle. With the vast nationwide network of FUGs at work, both formal and informal, the latter awaiting official recognition by forest authorities according to their convenience, Nepal was able to restore its forest wealth in about a mere decade's time. To give some insight in its participatory management system, an American researcher had observed in her Ph D thesis in 2002 that 'many user groups are equally distributing forest products and, in some instances, even incorporating concerns of equity by providing greater shares to occupational and low caste members", "women's confidence and participation in user groups and collective processes of decision-making is increasing", "User group chairmen are listening to the concerns of group members" and that "Participation in discussions and decision-making is increasing" and so on (Britt, Charla Danelle, 2002, 204205). While the World Future Council based in Hamburg, Germany had recognized Nepal's forest policy as "one of the best in the world" in 2011, the Nepal government itself had officially offered to "share its successful experience and expertise in community forest management" with the rest of the countries in South Asia in the 2016 Mini SAARC Summit held in Nepal. Such approaches need to be adopted across all sectors of development so that everybody effectively benefits irrespective of their difference in caste, ethnicity, gender or economic status. This requires a fundamental reformulation to our national polity, sooner the better.

\section{References}

Ahiraj, R. (2018). Interview given to the news portal Desh Sanchar on Fagun 29, 2075 BS

Anderson, B. (2016). Imagined Communities: Reflections on the origin and spread of nationalism. London: Verso.

Balcells, L. (2019). FOREIGN AFFAIRS 27, 2019,

Britt, C. D. (2002). Changing the boundaries of forest politics; Community forestry, social mobilization and federation-building in Nepal viewed through the lens of environmental sociology and PAR, A Dissertation Presented to the Faculty of the Graduate School of Cornell University in Partial Fulfillment of the Requirements for the Degree of Doctor of Philosophy

Burkert, C. (1997). Defining maithili identity: Who is in charge? In David N. Gellner et al (ed.) Nationalism and ethnicity in a Hindu Kingdom: The Politics of culture in contemporary Nepal. The Netherlands: Harwood Academic Publishers 
Dev, R. N. (2012). Tarai-Madheshma arakschyan nitikasto hunu parchha?Kantipur, Baisakh 26, 2069 (May 8, 2012)

Dhading DDC (District Development Committee) (2002). District profile of Dhading district, Dhading

Gellner, D. N. (1997). Ethnicity and nationalism in the world's only Hindu state. In David N. Gellner et al (ed.) Nationalism and ethnicity in a Hindu kingdom: The politics of culture in contemporary Nepal. The Netherlands: Harwood Academic Publishers

Guneratne,A.(2009). “Introduction”. Regionalism and National unity in Nepal by Federick H. Gaize, first published 1975, Reprint published by Himal Books for Social Science Baha, Kathmandu.

Gurung, H. (1997). State and society in Nepal. In David N. Gellner et al (ed.) Nationalism and ethnicity in a Hindu kingdom: The politics of culture in contemporary Nepal. The Netherlands: Harwood Academic Publishers

Kailali DDC. (2009). District development plan, 2009/10, Dhangadi

Kishore, C. (2012). Wariparika Bachhita, Kantipur. August 16.
Kohn, H. (2019). Nationalism. Encyclopedia Britannica 2019.

Onta, P. (2011). Advasi/janajati: definititonal politics of the past and the future, Republica, July 29, 2011,_Kathmandu

Pradhan, R. (2002). Ethnicity, caste and a pluralist society, in state of Nepal, by Kanak Mani Dixit and ShastriRamachandran (ed.), Lalitpur: Himal Books

Sharma, B. (1951). Nepal ko Aitihasik Rooprekha, Varanasi:

Sharma, P. R. (1997). Nation-Building, Multiethnicity, and the Hindu state. In David N. G. ed. (1998). Nationalism and ethnicity in a Hindu kingdom: The politics of culture in contemporary Nepal. The Netherlands: Harwood Academic Publishers

Sharma, S. (2019). The Nepal Nexus: An inside account of the Maoists, the Durbar and New Delhi: Penguin Random House

Shrestha, B. K. (2012). Federalising back to the Baise Chaubise days: An anthropological perspective on ethnicity as the basis for state restructuring in Nepal, Ethnicity and federalisation in Nepal, Central Department of Sociology/Anthropology, Tribhuvan University, Kathmandu. 